\title{
The art of nursing in a 'postmodern' context
}

Philip Lister RMN RNT RCNT CertEd (FE) Dip Applied Social Sciences Senior Lecturer, School of Health Studies, Nursing and Midwifery, 14orcester College of Higher Education. Henwick Grove, Aorcester WR26AJ, England

Accepted for publication 15 January 1996

LISTER P. (1997) Journal of Advanced Nursing 25, 38-44

\section{The art of nursing in a 'postmodern' context}

Notions of the postmodern pervade various fields of study, but have rarely been applied to the practice and theory of nursing. This paper uses some conceptions of the 'postmodern' to remedy this. Though there are many contested usages of the term, here 'postmodern' will be used broadly in a periodical sense to trace changes in society and Culture from the 'modernism' of the 18th and 19th centuries to current concerns about postmodernism. How these changes have been reflected in nursing practice and nursing theory will be explored. The changing use of the term 'modern' to describe up-to-date practice will be addressed in the course of this. It is suggested that contextualizing nursing as a social/cultural activity in this way offers perspectives which will help us untangle the conflicting agendas and issues which form the fabric of the social world in which current nursing takes place, enabling us to act more effectively in promoting our own professional agendas.

\section{INTRODUCTION}

The aim of this paper is to contextualize 'nursing', both as an activity and as a discipline. It will explore how changes in society and in culture have shaped nursing. The focus will not be on specific technical developments, but more on the way that 'nursing' is thought of in relation to broader trends within cultures. It will be seen that issues and concerns in present-day nursing both reflect current dominant discourses and carry traces of past discourses. The hypothesis is that tensions within nursing will be more easily understood (and therefore more effectively coped with) if they can be related to wider social and cultural trends.

To some extent this is currently addressed through the inclusion of the sociological and social policy perspectives in pre- and post-registration programmes. What this paper offers is a broader perspective from the field of what might be called cultural studies. It is an attempt to locate the present of nursing in a cultural and historical context. The notion of 'postmodernism' will be crucial to an understanding of nursing's present context. Firstly, the question of what is meant by the term 'modern' will be addressed - what is 'modern' nursing? The 18th century Enlightenment project and the 19th century Industrial Revolution with its concomitant Marxist critique will be explored here

The effect of the two world wars on society and culture will be related to changes in nursing, especially the effects of the subsequent Cold War politics on discourses about what it now meant to be 'modern'. The breakdown of this consensus about modernism in the 1970s will then be explored, especially with regard to how 'postmodern' concerns are reflected in current ideas about nursing, 
and in the social context where nursing exists. Two sets of implications for nursing and health care will be drawn out - a surface optimistic view and a deeper critical view.

\section{DEFINING THE MODERN}

Before we can understand what is meant by the term 'postmodern' we need to engage with some questions about what we mean by the term 'modern'. When did the 'modern' period begin? What differentiates this period from the one before? What do we mean by being a modern nurse? The word 'modern' has a French derivation, meaning 'the just now' (Williams 1988), in common usage it is often differentiated from some time or practice which was 'traditional'. It was first used to describe a certain type of nursing in the 19th century, exemplified by innovations in conceptualization and practice attributed to Florence Nightingale.

Hector (1982) agrees with Nightingale that 'modern' nursing began in the middle of the 19th century. Simnett (1986) identifies this period as significant in that 1860 saw the beginning of a process of reform which established nurse training and the powers of the Matron in general hospitals. This ran parallel to - but independent of - the beginnings of training for attendants in lunatic asylums (Nolan 1993). These movements began to chart a course away from the traditional intuitive role of the nurse towards a more educated - or at least instructed - role.

This period is also seen by some historians and cultural critics as the time when the 'modern' period began. Baudelaire, for example, described the condition of 'modernité' in art at that period. For him, this was 'the transient, the fleeting, the contingent; it is that one half of art, the other being the eternal and the mutable' (Baudelaire 1964 p. 13). Whereas established art practice had hitherto been about the eternals of man's (sic) condition, modern art should represent something of the ephemeral nature of individual lives. A modern sensibility would therefore be focused less exclusively on tradition and the past, but equally on the present moving into the future.

\section{The Enlightenment project}

For other writers, modern times began with the Enlightenment of the 18th Century (Sarup 1988). Religion, superstition and tradition had hitherto given meaning and direction to human activity. In this new period it was to be reason which would govern human affairs. To be a part of this new liberalism - this freedom (liberté) of the individual - was to be modern.

Medical care began to extricate itself from the Christian Church at this time, and scientific experiment through applied reason was to lead to advances on this front. The occupation of nursing did not, however, significantly alter until the mid-19th century, as identified above.

\section{The Industrial Revolution and its Marxist critique}

This change ties in with the beginnings of 'modernization' ushered into western Europe by the Industrial Revolution. This period saw huge social changes which made life significantly different from the preceding times. For Marx, it was the rise in power of industrial capitalists against the decline of aristocratic landowners which made this period significantly different (Coates 1990).

Marx also noted how unfettered free-market capitalism led to rapid and continual social change, against the more settled times prior to this. He noted that a feature of the modern condition was 
that 'all that is solid melts into the air' (Marx \& Engels 1848 p. 38). He presumed that as capitalists continued to exploit resources and people, and as the system continued to produce dislocations and disruptions for the workers, there would be an inevitable point at which the workers would revolt and take ownership and power for themselves.

Engels had already identified how a capitalist economy inflicted death and illness on the labouring classes. Referring to the English property-owning class, he accused it of 'social murder' (Engels 1845 p. 121) in subjecting manual workers to lethal occupational and domestic conditions.

The communist revolution of 1917 in Russia accelerated a growing concern in other European nations about the quality of life of their own labouring classes. Conditions which might lead to revolution and thus disruption of capitalist enterprise would need to be addressed (Thompson 1918, Doyal 1979). One of these concerns was with health, and the state provision of health care took a higher priority along with other aspects of Social Welfare. This was intended to put a brake on the 'inevitable' slide to revolution.

Another brake was provided by the two world wars. For some, these wars proved the inadequacy of the Enlightenment project. Reason and science had become applied to prejudice, nationalism and power-seeking politics to atrocious effect (Horkheimer 1974). But the resulting peace brought with it a consensus for rebuilding the future. This continued the pre-war Enlightenment expectation of continual progress towards a better future, but with a degree of realism tempered by recent history. This future-orientation continued a feature of post-Enlightenment modernism.

Underlying this optimism were continual developments in technology, mass media, entertainment, and science which took to new levels discoveries and inventions from the 1890s and 1900s (Appignanesi \& Garrat 1995). These accelerated the experience of social and cultural change.

\section{CONCERN WITH "WELFARE"}

The United Nations Organization (UN) was formed as a modernist project at this time, universalizing such things as 'human rights', which included the right to socio-economic welfare (Jones 1990). This growing concern with the people's 'welfare" led many countries in the developed western world to institute their own state-run welfare systems as part of the post-war reconstruction (Titmuss 1950, Lowe 1993).

The aim was the eradication of the social problems uncovered (to the ruling classes) by the world wars. The long-standing deleterious effects of industrialisation would at last be countered, providing healthy societies moving forward collectively (Taylor \& Field 1993), but without the need for Communistic revolution.

What was 'peculiarly modernistic' about this (Barry 1990 p. 7) was the elevation of what had been seen as peripheral responsibilities of government - socioeconomic welfare for all - to the same level of importance as those functions usually considered as central, such as law and order, continuity and social cohesion (Barry 1990).

The move to state welfare was not without its critics. In Britain, for example, the British Employers Confederation (BEC) expressed the view that the economic performance of the country should take priority over welfare concerns (BEC 1941, in Hay 1978). Welfare expenditure should be directly 
linked to industrial performance, and should not weaken incentives to work. This was, of course, a straightforward capitalist argument. It could be read as an insistence on maintaining profits and wealth at the expense of general socio-economic welfare.

Some analysts of the modern welfare state have identified how conflicts of interest have come to be embedded within this apparatus. For example, Walker (1991) argues that the welfare state reflects the capitalist values and social relations which are part of the fabric of the industrialized world. As well as protecting people from the stark consequences of a free market economy (Titmuss 1974), the Welfare state also represses and controls people through surveillance of everyday life (Foucault 1979) and through the control of access to services and resources.

However, at the time of its inception in various countries post-second world war, the welfare state was regarded as a thoroughly modernist invention which would transform the world and its countries.

In the period where modernism was the dominant trajectory, nursing began to be a future-oriented profession. It saw itself as having historical and venerable roots and modern future goals, both as a player within the welfare state and as a career for individuals.

\section{NURSNG AS AN INDUSTRY}

In industry, Henry Ford's development of the production-line brought in a new paradigm of work. Specific tasks were assigned to individuals along the production-line in the name of efficiency (Giddens 1989). The finished product was always completed elsewhere. This efficient method of factory production became a model for other types of work. The 'task-allocation' system of nursing was typical of this, and is thus very firmly of its time (Walby 1994). Like the production-line worker, the essential task for the working nurse was to complete the routines allocated. The 'whole patient' was not the central concern of the individual nurse in this system, as the 'whole car' was not an individual worker's responsibility.

Power was organized hierarchically, shadowing political and industrial power structures. The 'scientific management' of Taylor (1911) proved a pervasive influence on industry - including the health industry (Joseph J994). The Taylorist discourse of 'management by objectives' even now pervades nursing and health care, from government policy to trust charters to the nursing process as a way of structuring nursing activity. Nursing also began to establish for itself such theoretical constructs as 'models of nursing' which articulated the underlying structure of all the different activities which were called 'nursing'. These models were produced in an academic context of designing courses at degree level and above. At this level models had to represent nursing as being an activity which could withstand intellectual scrutiny. But in the course of this they framed nursing within a highly rationalized discourse, rooted in the same ground as the scientific aspects of medical practice.

\section{Redefining the art of nursing}

In redefining what constituted nursing against the traditional 'doctor's handmaid' image, the debate was contested on medicine's ground. And medicine's claim to 'rationality' was rooted in the modernism of the Enlightenment. This redefinition of the nature of nursing can also be linked to concepts of 'modernism' in the field of culture. 
Clement Greenberg rose to prominence in the early 1960s in the field of art criticism/history. His construction of what constituted proper and great 'modern' art defined the terms of art discourse into the late 1970s. In the face of photography, film and other forms of reproduction, painting had to establish its special relevance. For Greenberg, this meant that 'each art had to determine, through its own operations and works, the effects exclusive to itself. By doing so it would, to be sure, narrow its area of competence, but at the same time it would make its possession of those areas all the more certain' (Greenberg 1982 p. 309).

What Greenberg endorsed was the art of American Abstract Expressionism, which internationally became the paradigm for modern art. It was represented as being purely individualistic, with artists developing their own completely different styles. However, the CIA sponsored touring exhibitions of this art in Europe promoting American/Western ideologies of liberal individualism against the threat of communist Eastern Europe, despite the mixed sympathies of the artists represented (Cockcroft 1974).

It was during this time that in America, nursing was becoming concerned with a redefinition of itself. Nurse theorists were trying to express the effects exclusive to nursing. While this can be read as tying in with a concern for professional identity and status (Salvage 1985), it can also be read as being typically part of a modernist project,

\section{Virginia Henderson}

Virginia Henderson's (1966) classic definition established the nurse's function as being concerned with the individual at the interpersonal level. She wrote that

'The unique function of the nurse is to assist the individual, sick or well, in the performance of those activities contributing to health, or its recovery (or to a peaceful death) that he would perform unaided if he had the necessary strength, will or knowledge.' (Henderson 1966 p. 15)

This modernist stance clearly outlines the nature of nursing which is unique or 'exclusive to itself" (in Greenberg's words) and reifies the individual at the centre of the work. While this individualized focus can be seen as a progression from task-allocation towards primary nursing (Manthey 1970) and part of a humanist trend in the development of nursing care, it is inescapably shaped by the Enlightenment discourse of the primacy of the individual.

This is accepted uncritically in recent texts so that it can be said that the 'philosophy of nursing in the 1990s is firmly rooted in recognizing people as individuals with specific wants and needs' (Dougan 1995 p. 63). It may be difficult to register anything problematic with this, but the other side of the coin emphasizes the primacy of individual responsibility for health so that another part of the text 'aim [s] to provide an understanding of how individuals make decisions about their health status' (Steele 1995 p. 31) and then goes on to use social psychological concepts to discuss health promotion. The modernist and authoritarian agenda of social psychology has recently been critiqued (Stainton Rogers et al. 1995) and the victim blaming theories of disease informing health-promotion picked up by writers such as Seedhouse (1986).

So, being formed within a modernist discourse, it could be argued that modern nursing carries within it some basic assumptions which need to be queried and worked against. One cultural 
perspective that may assist in this reviewing is the set of counter-discourses described as 'postmodernism'.

\section{DEFINING THE POSTMODERN}

The term 'postmodern' has a variety of (contested) usages. Firstly, in philosophy it refers to critiques and theories typified by Foucault (1970), Derrida (1976) and Deleuze \& Guattari (1984). They stress the plural, fragmentary and subjective nature of reality and of the self. Secondly, in the arts it refers to a negation of the 'modern' movements in painting, architecture and literature, and a focus on the power and nature of representational systems within culture. Thirdly, in social studies it refers to social and political transformations in the western world brought about by 'post-industrialization', information technology and the breakdown of consensus politics (Callinicos 1989, Harvey 1989, Layder 1994). It is this third usage that concerns us most here.

\section{Global and national changes}

As the post-war period progressed, the 'modernist' ideas of freedom through technology, etc., began to wane. Technology, whilst supplying consumer durables to the home, was also threatening domestic stability by creating weapons of mass destruction. Behind all this was the battle of the superpowers for global supremacy. This was also fought out ideologically in the Third World health care field. The USSR-sponsored Cuban health care system helped train many doctors from other Third World countries, to help introduce a socialist alliance (Perez 1982). At the same time, western aid programmes were used for advancing American-led capitalism (Mende 1973).

In the United Kingdom (UK), consensus politics broke down in the 1970s, allowing capitalism to reassert itself after the hiatus of the world wars. The welfare ideals were not being delivered in an economy which did not prioritize them, but which saw the accumulation of wealth as the main social goal. The State was seen as holding back the individual from participating in the 'free market" (Jones 1994).

Global capitalism in the form of multinational companies and the money market meant that the political process in any individual country could have only a limited effect on that country's lifeworld (Giddens 1989, Robins 1990, Dunning 1993). Short-term interests took precedence in the casino of the international economy and became structured into the political imagination, where policy would deal with immediate concerns and leave 'market forces' to meet long-term needs.

These 'post-modern' times can be seen as a return to the industrial/capitalist enterprise critiqued by Marx but disrupted by the world wars. Again, we are living in a world where 'all that is solid melts into the air'. The model of the free-market has been introduced into areas dealing with more than material product. Continual upheavals in the UK's National Health Service exemplify this, to the extent where a contractual culture has been structured into the system - ensuring periodic review, change and disruption in place of a managed development. Competition between providers ensures lack of cooperation between them, and undercuts the principles assumed in community care legislation to work in 'partnership'. The job of nursing in this new situation has changed. The notion of a 'career' in a dynamic market with high underlying unemployment is difficult to sustain.

\section{Nursing the Consumer}


'Consumerism' is a paradoxical ingredient in free-market enterprise (Jones 1994). The consumer is the source of wealth for capital investinent, and therefore has to be placed near the centre displacing professional and expert groups of employees. The prioritizing of the consumer is reflected in such projects as the Asian Mother and Baby Campaign in the UK in 1984 (Rocheron 1990).

\section{IMPLICATIONS FOR CARE DELIVERY}

\section{The uncritical view}

The focus of nursing in relation to the patient has changed. Alongside 'traditional' (note how this term gets continually displaced) task-allocation, a new orientation to giving 'holistic' care is encouraged. This is even represented in the UK government-promoted 'named nurse' initiative, where each patient has a named nurse to coordinate her or his care (Department of Health 1991). This flatterns the hierarchy in a ward team to some extent, and provides the possibility of multiple viewpoints within a negotiated approach.

The fluid restructuring of health care systems and professions in a postmodern society could bring benefits for clients and workers. There is a move to increase client choice and even control. If party political processes and professional power groups will begin to become disestablished, the role of special interest groups may become more important. Users' groups such as Britain's MIND and Age Concern would have a growing influence on local and national social policies. These agencies involve and campaign on behalf of people with experience of mental disorder (MIND) and the over-65 age group (Age Concern).

Nurses would increasingly be able to use their professional power to empower their clients, rather than use power on their behalf in a parentalistic way.

The devolution of power to the local level offers the opportunity to shape local health care systems to fit local needs. The disaggregation of power from the centre to the periphery can also be reflected in flattened hierarchies with more power and responsibilities given to the professional at ground level with as much accountability to users as to their peers.

For the nurse as a worker, if the notion of a lifelong career disappears then mixed patterns of work over time may become the norm. 'Career breaks' may not need to be explained awkwardly at interviews but can be planned and incorporated into new life patterns.

\section{The critical view}

There are, of course, potential problems in this 'postmodern' world. It is still a capitalist world where the profit motive and the accumulation of capital is seen as normal, natural and valuable. Many accounts of postmodernism ignore this fact, which seems a glaring omission (Callinicos 1989). It would seem Marx's analysis of conditions in a newly industrialized Europe of the 19th Century are no less relevant now. Perhaps they are more relevant, given the breakdown of post-war consensus, and capitalism's new-found confidence given the breakdown of the Soviet Union. Marx's analysis of the relations of power in a capitalist world remain convincing, if his optimistic belief in inevitable revolution is less so (this historical optimism defines Marx as a modernist writer). 
As the State withdraws from welfare provision and encourages privatization of these services, the care providers will need to show a profit. The more successful operators - following patterns in industry - could buy out smaller companies and monopolies would be created.

Operators will need resource flexibility to adapt to changing needs and conditions and maintain a competitive edge. Nationally fixed pay rates are an obvious obstacle here, hence the UK government's attempt to impose a locally negotiated pay structure. This reflects wider industrial (post-Fordist) trends towards a more flexible workforce in terms of both skills and numbers where a reduced core of full-time staff is supplemented by a flexible part-time workforce (Warde 1990).

In nursing teams, the covering of staff shortages by bank nurses can then be seen not as crisis management but as a deliberate though unadmitted strategy of 'numerical flexibility' (Warde 1990 p. 87). However, this disrupts nurses' concerns with ensuring continuity of care, with establishing therapeutic relationships with clients, and with providing holistic care. If continuity of personnel is mot structured into the system then nursing's aspirations to quality care cannot be achieved.

Such fragmentation of care is both 'unintended and inevitable' (Fox 1993 p. 59) when, in place of a modern coordinated health care system we have an attempt to disassemble it into a postmodern environment of small 'organic' organizations competing for trade. This 'organic' metaphor suggests a social Darwinism that is implicit in the discourse of 'market forces' (Morgan 1986). One problem with this metaphor is that it blinds the user to the fact that the 'environment' (capitalist economic structure) is socially constructed rather than a natural and implacable fact.

The fragmentation of care brought about by this ideology brings to the surface competing discourses such as managerialism, economics, politics, nursing, doctoring and consumerism. Temporary alliances or overlapping of interests make it possible for certain groups to influence the structures of care provision at various levels at opportune moments but could work against long-term strategic development.

\section{CONCLUSIONS}

The Concepts of 'modernism' and 'postmodernism' have been used by historians, philosophers and cultural theorists to identify changes in the lifeworlds of citizens of the developed countries. On the one hand, they represent different periods of time within a society, e.g. preindustrial, industrial and post-industrial. On the other, they represent different paradigmatic ways of constructing the social world.

At worst, ideas of the postmodern can be said to justify acceptance of the conditions of late capitalism - offering pastiche in the place of passion, docile consumerism in the place of critical engagement (Callinicos 1989). Or they can offer perspectives which help us disentangle conflicting agendas and issues which form the fabric of the social world in which modern nursing takes place.

Nurses will remain enmeshed in these social processes as they affect whatever nursing comes to involve - their lives as employees, and the lives of the client groups they work with. Critical theories developed in other disciplines should be applied and tested in nurses' own field. This paper offers a theoretical view to enhance an understanding of the conflicting issues which nursing is having to deal with through exploring one version of the 'postmodern' and positioning western nursing in an historical and cultural context. 
An awareness of these cultural and historical shifts could enable nurses to more effectively tackle issues at a local and national level by providing a broader perspective on currents in the sociocultural-political world which are impacting on nursing practice.

\section{References}

Appignatesi R. \& Garrat C. (1995) Postmodernism for Beginners. Icon Books, Cambridge, Barry N. (1990) Welfare. Open University Press, Milton Keynes.

Baudelaire C. (1964) The Painter of Modern Life (Mayne J, trans.), Phaidon Press, London (From Baudelaire C. (1863) Le peintre de la vie moderne. Figaro, November 26, 28, December 3).

Callinicos A. (1989) Against Postmodernism: A Marxist Critique. Polity Press, Cambridge.

Coates D. (1990) Traditions of social thought. In Society and Social Science: a reader (Anderson J. \& Ricci M. eds), Open University Press, Milton Keynes, pp. 240-294.

Cockcroft E. (1974) Abstract Expressionism; weapon of the Cold VWar. Artforum 15(10) 39-41,

Deleuze G. \& Guattari F. (1984) Anti-Oedipus: Capitalism and Schizophrenia. Athlone, London.

Departinent of Health (1991) The Patients Charter. HMSO, London

Derrida J .(1976) Of Grammatology, John Hopkins University Press, Baltimore.

Dougan E. (1995) The Role of the Nurse. In Understanding Nursing Care (Peattie P. \& Walker S. eds.). Churchill Livingstone, Edinburgh, pp. 63-90,

Doval L. (1979) The Political Economy of Health. Pluto Press. London

Dunning J (1993) The Globalisation of Business. Routledge, London

Engels F. (1845) The Condition of the Working Class in England (reprinted 1969). Panther Books, London.

Foucault M. (1970) The Order of Things Tavistock. London.

Foucault M. (1979) Discipline and Punish. Penguin, Harmondsworth.

Fox N. (1993) Postmodernism Sociology and Health, Open University Press, Milton Keynes,

Greenberg C. (1982) Modernist painting. In Modern Art and Modernism (Frascina F. \& Harrison C, eds), Harper and Row, London. (From Greenberg C. (1965) Modernist painting. Art \& Literature 4, 193-201).

Giddens A. (1989) Sociology. Polity Press, Carnbridge.

Harvey D. (1989) The Condition of Postmodernity. Basil Blackwell, Oxford.

Hay T. (1978) The Development of the British Welfare State 1880-1975, Edward Arnold, London.

Hector W. (1982) Modern Nursing: Theory and Practice. Heinemann, London. 
Henderson V. (1966) The Nature of Nursing. Macmillan, New York.

Horkheimer M. (1974) Critique of Instrumenial Reason: lectures and essays since the end of World War II. Seaburg Press, New York.

Jones L. (1994) The Social Context of Health and Health Work. Macmillan, London.

Jones P. (1990) Universal principles and particular claims, . In Needs and Welfare (Ware A. \& Goodin R, eds), Sage, London, pp. 34-53.

Joseph M. (1994) Sociology for Nursing and Health Care. Polity Press, Cambridge.

Layder D. (1994) Understanding Social Theory. Sage, London.

Manthey M. (1970) Primary Nursing. Nursing Forum 9(1), 65-83.

Marx K. \& Engels F. (1848) The Manifesto of the Communist Party. In Selected Works in One Volume (Marx K. \& Engels F.), Lawrence and Wishart, London, pp. 31-63. (From Marx K. \& Engels F. (1848) Mainifest des Komunministischen. Burghard, London).

Mende T. (1973) From Aid to Recoloniscation. Harrap, London.

Morgan G. (1986) Images of Organization, Sage, London.

Nolan P. (1993) A History of Mental Health Nursing, Chapman \& Hall, London.

Perez L. (1982) Cuba: Internal and international affairs, Sage, London.

Robins K. (1990) Global local times. In Society and Social Science: a reader (Anderson J. \& Ricci M, eds), Open University Press, Milton Keynes, pp. 196-205.

Rocheron Y. (1990) The Asian mother and baby campaign: the construction of ethnic minorities' health reeds. In The State or The Market (Loney M, Bocock R, Clarke J, Cochrane A, Graham P, Wilson M. eds), Sage, London, pp. 184-206.

Salvage J. (1985) The Politics of Nursing. Heinemann, London.

Sarup M. (1988) Post-Structuralism and Post-Modernism. Harvester Wheatsheaf, London.

Seedhouse D. (1986) Health: The foundations for achievement, John Wiley and Sons, London.

Simnett A. (1986). The pursuit of respectability. Women and the nursing profession, 1860-1900. In Political issues in Nursing: Past, Present and Fulture Vol. 2 (White R. ed), John Wiley and Sons, Chichester, pp. 1-25.

Sainton Rogers R, Stennier P, Gleeson K, \& Stainton Rogers W. (1995) Social Psychology: a critical agenda. Polity Press, Cambridge,

Steele P. (1995) People in health, in Understanding Nursing Care (Peattie P. \& Walker S. eds), Churchill livingstone, Edinburgh. pp. 31-62.

Taylor F.W. (1911) Principles of Scientific Management. Harper \& Row, New York. 
Taylor S. \& Field D (1993) Sociology of Health and Health Care. Blackwell Scientific, London.

Thompson B. (1918) The seeds of revolution? in The Development of the British Welfare State 18801975. Hay J. (1978) Edward Arnold, London, pp. 24-25.

Titmuss R. (1950) Problems of Social Policy, Longmans, Green \& Co., London

Titmuss R. (1974) Social Policy. George Allen \& Unwin Ltd., London.

Walby S. (1994) Medicine and Nursing: Professions in a changing health service. Sage, London.

Walker A. (1991) The social Construction of dependency in old age. In The State or the Market (Loney M., Bocock R., Clarke J., Cochrane A., Graham P. \& Wilson M, eds), Sage, London, pp. 41-57.

Warde A. (1990) The future of work. In Anderson \& Ricci op.cit pp. 86-95.

Williams R. (1988) Keywords: A Vocabulary of culture and society, Fontana Press, London. 